\title{
Køn, klasser og kropskultur
}

\author{
af Hans Bonde
}

Den mest grundlæggende erkendelse i den moderne sportsforskning er, at den vestlige konkurrencesport ikke er den eneste eller naturlige form for kropslig udfoldelse. Tværtimod er den i et historisk lys kun den foreløbige efterfølger til mange, meget forskelligartede kropskulturer:

Der er f.eks. en verden til forskel på 1700' tallets elegante adelsmand, som med nette, sirlige og fine bevægelser dyrkede ridning eller fægtning, og så den moderne atletikløber, som med stærke, spændte muskler i en kamp mod uret haster fremad mod et mål i det fjerne. Der er et bevægelsesmønster til forskel, men der er også en krop til forskel (muskler, åndedræt, holdning o.s.v.). Og der er også en tankegang - et syn på sig selv og sin krop - til forskel.

Når jeg i det følgende bruger ordet sport, mener jeg derfor altid den moderne vestlige konkurrencesport i modsætning til mange andre former for kropskultur, som måske slet ikke bygger på konkurrence.

Denne erkendelse medfører, at sporten forstås som samfundsmæssigt bestemt fremfor naturgiven, hvilket igen medfører at sportsaktiviteterne analyseres i relation til det øvrige samfundsliv.

I denne artikel vil jeg med udgangspunkt $\mathrm{i}$ mit specialearbejde om „,sportens gennembrud i Danmark, 1866-1914“" forsøge at diskutere nogle centrale elementer i sporten. Elementer som netop peger ud over sportens snævre horisont, ud mod det øvrige samfund. Og jeg vil hermed også forsøge at pege på, hvad jeg opfatter som vigtige forskningsmuligheder fremover. Artiklen skal dog absolut ikke forstås som et sæt færdige løsninger, men snarere som et idékatalog og et debatoplæg.

Artiklen er opdelt i syv afsnit. I de første to afsnit forsøger jeg at analysere den tidligere danske sport som en enhed af frigørende og undertrykkende elementer. Og jeg ser på sportens rolle for en formning af karakterstrukturen. I forbindelse hermed ser jeg i afsnit tre på forholdet mellem sport og politik. Det fjerde og femte afsnit handler om køns- og klasseaspekter i den tidlige danske sport. Og i de sidste to afsnit vil jeg diskutere forskellige aspekter af sportens møde med fremmede kropskulturer. De centrale eksempler er her dels „sportshjælp“ som led i u-landsbistanden, og dels den japanske kampkunst judo's forvandling til en moderne konkurrencesport. 


\section{Frigørelse og tvang}

I løbet af 1970'erne koncentrerede den marxistiske sportsforskning sig næsten udelukkende om at analysere sporten som en aktivitet, der skulle lære arbejderne at konkurrere med hinanden, og præstere en stor arbejdsindsats til gavn for arbejdskøberne. Og som et middel til at give arbejderne energi til at kunne udholde endnu en dags nedslidende arbejde.

Efterhånden er det imidlertid blevet tydeligt for mange, at når man udelukkende har for øje, at sporten kan virke indoktrinerende og gavne kapitalismens fortsatte beståen, så har man kun fat i den halve sandhed. Det bliver nemlig umuligt at besvare mange helt grundlæggende spørgsmål, som f.eks. hvorfor mennesker frivilligt skulle lade sig undertrykke og fordumme, og hvordan sporten har kunnet udvikle sig til Danmarks største folkelige bevægelse. Sporten må kort sagt indeholde nogle aspekter som kan fascinere og virke befriende for idrætsudøveren.

I de senere år er det da også blevet mere og mere almindeligt at forstå sporten som en enhed af frigørende og undertrykkende elementer. (Se f.eks. Hans Jørgen Nielsen, Fodboldenglen, 1979 og Bidrag, Sport og Fascination, 1981). Denn erkendelse har imidlertid endnu ikke sat sig særlige spor i det der er skrevet om sport. I det følgende vil jeg derfor forsøge at give et helt kort rids over nogle af de væsentligste frigørende momenter ved den danske sport, som den udviklede sig i byerne i perioden 1880-1914.

Inden da vil jeg dog understrege at sportsbevægelsen helt op til 1914 havde ret få aktive udøvere. Før århundredeskiftet var det faktisk først og fremmest unge mænd, som stilede mod en karriere inden for erhvervslivet, som havde mod og ressourcer til at dyrke sport.

Sportens pionerer, som altså ofte var ,,borgerlige opkomlinge“, var i strid modvind $\mathrm{i}$ store dele af det bedre borgerskab, som sandsynligvis $\mathrm{i}$ vid udstrækning anså den nye konkurrencesport for at være overdrevent kropslig, beskidt, helbredsmæssigt farlig og frem for alt udannet.

Frem til århundredeskiftet var der kun ganske få arbejdere, som dyrkede sport. Deres lange arbejdsdag og ringe løn var en afgørende hindring.

Der ligger imidlertid allerede i begrebet frigørelse en række uløste problemer, som jeg ikke kan diskutere her. Som et foreløbigt udgangspunkt vil jeg dog foreslå, at frigøre/se skal forstås subjektivt som det den enkelte gruppe el. det enkelte individ opfatter som en befrielse. Denne definition vil sikre, at vi ikke forveksler det vi i dag føler er frigørende med det datidens mennesker følte var befriende.

De følgende eksempler på frigørende aspekter er næsten alle resultater af en analyse af tidlige borgerlige sportsbøger og -tidsskrifter, og kan derfor siges primært at udtrykke holdninger hos den sportsbegejstrede del af borgerskabet. 
I idrætslitteraturen opfattedes sporten som en befrielse fra gamle snærende bånd på flere områder:

For det første betød sporten for overklassen et gennembrud for et nyt syn på kropskontakten mellem mennesker. Billedanalyser kan f.eks. vise at mænds berøringer af hinanden blev mere acceptabel $i$ forbindelse med sportsudøvelsen.

For det andet spillede den tidlige sport en helt central rolle for udviklingen af en klædedragt som tillod en større bevægelsesfrihed. Og heri lå der også et gennembrud for et mere frisindet syn på nøgenhed i den borgerlige kultur. Stadig flere legemsdele kunne nu tåle dagens lys.

For det tredje udgjorde sporten et af de få frirum, hvor borgerskabets mænd kunne mødes under relativt uforpligtende former.

Og for det fjerde var sporten - ligesom spejderbevægelsen - led i en bevægelse ,tilbage til naturen“. Nu skulle kontorets, fabrikshallens og gymnastiksalens lukkede rum gennembrydes af „,frie Lege i frisk Luft og varmt Solskin" (W. Hovgaard, Sport. 1888), kort sagt af sport. Ud fra en analyse af arbejdersportstekster ses det, at også mange arbejdere følte sig tiltrukket af denne, grønne bølge“".

$\mathrm{Nu}$ kan man selvfølgelig hævde at disse eksempler på frigørelse set med nutidens øjne er lidt pauvre.

Men så ser man helt bort fra, at tiden omkring århundredeskiftet - især for de højere lag i byerne - var karakteriseret ved at kropskontakten mellem mennesker ofte var indskrænket til ægteskabelige favntag, prostitution og lægens kliniske berøring af sin patient. Og at manien med at spærre mennesker inde i lukkede rum (fabrikker, skoler og anstalter) og sågar $\mathrm{i}$ deres eget tøj (korset, knækflip o.s.v.) netop i denne periode havde kronede dage.

Konkluderende vil jeg sige, at det midt $i$ industrialiseringens voldsomste fase må have været en befrielse for arbejdersportsmanden efter en 60 timers arbejdsuge at forlade fabrikkens indeklemte, støjénde og udpinende miljø og løbe ud på grønsværen sammen med gutterne. På samme måde med fabrikanten eller sagføreren som på tennisbanen kunne tillade sig at smide knækflip, habit og de alvorlige ansigtsfolder for $\mathrm{i}$ et par timer i bogstaveligste forstand at lade kroppen folde sig ud.

\section{En stålsat karakter}

Det spørgsmål som nu melder sig er: Hvordan kunne disse frigørende elementer blive udviklet $i$ et samfund, som var præget af en voldsom kapitalistisk udvikling, og som derfor $\mathrm{i}$ alle andre henseender krævede 
(selv)disciplin og arbejdsmoral af samfundsmedlemmerne?

Ved en analyse af den tidlige borgerlige idrætslitteratur viser det sig, at sportens vigtigste funktion ikke skulle være at ,frigøre kroppen" og heller ikke f.eks. at skabe fysisk sundhed. Igen og igen slås det fast, at sporten først og fremmest skulle udvikle og hærde en stålsat karakter, altså styrke selvdisciplinen.

Lyt blot til det fængende budskab til den danske ungdom fra denne danske sømandspræst i London:

„Man kan tilføje at de Unge (englændere, min anm. HB) netop paa Grund af Idrætten er saa solide, idet den giver dem en Selvbeherskelse, som præger hele deres Liv. Man ryger ikke, drikker ingen Spiritus og nyder intet uden den simple, kraftige Kost, når man bereder sig til Kamplegen. Det opdrager Ungdommen til en Selvbeherskelse, som hverken paalægges ved strænge Ord eller efterkommes med sure Miner. Denne Selvbeherskelse indpodes de Unge daglig Aaret igennem fra de er ganske smaa. Derved bliver den en Del af de Unges Karakter og han kommer til at gøre den Erfaring at den lønner sig ... han løber ikke vild efter Øjeblikkets Indskydelse. Han bevarer sig selv, derfor bliver han den herskende blandt sine Fæller" (tidsskriftet ,Idræt" 1901 nr. 3).

Det eftertragtede personlighedstræk var altså at beherske sig selv for at kunne beherske de andre.

I ,,kampen for tilværelsen“ var der ingen plads til blødsødenhed, og denne indøvning i selvbeherskelse skulle først og fremmest ske gennem den hårde træning, som krævede at alle former for luksus og driveri blev bandlyst. Gennem en bevidst styring og undertrykkelse af kropslige impulser, såsom lysten til at spise, drikke, sove og dyrke sex, skulle den unge mand lære at koncentrere sig om livets sande værdi: Karrieren. Opstigningen på sejrsskamlen var kun et skridt på vejen mod samfundets top.

Hvis vi vender tilbage til dette afsnits indledende spørgsmål kan det altså konstateres at ganske vist indeholdt sporten visse frigørende træk. Men disse træk blev underordnet sportens egentlige mål: Skabelsen af en ,,stålsat karakter" gennem indøvelse i selvtvang. Havde sporten imidlertid kun bestået af selvpineri, ville den aldrig have fået en så stor og til tider fanatisk tilhængerskare, som den har. Og det er netop heri dens fascinationskraft ligger; i dens evne til at forene modsætninger som f.eks. tilpasning og frigørelse.

Spørgsmålet er imidlertid om sporten stadig i dag kan siges at indeholde frigørende træk? Er der ikke snarere tale om at sporten lukkes mere og mere inde i store idrætshaller? Er sportens krav om afklædning og berøring ikke forlængst blevet en selvfølgelighed i hele samfundslivet? Og er denne udvikling ikke netop årsag til sportens krise og fremvæksten af alternative 
kropskulturer, som f.eks. joggingbevægelsen, der igen bryder med den indelukkede idrætshal? I alle disse spørgsmål ligger der oplagte forskningsmuligheder.

(Jvf. også flere af Henning Eichbergs artikler i „Centring“ samt Ove Korsgaards ,,Kampen om kroppen“, 1982, s. 339 ff)

\section{Sport og politik}

Den forudgående analyse af konkurrencesportens rolle for skabelsen af en ,,stålsat karakter“ kan også siges, at have en betydning for diskussionen om forholdet mellem sport og politik.

Inden for de sidste årtier har mange inden for den etablerede idrætsbevægelse, og ikke mindst lederne i Dansk ldræts-Forbund næsten udelukkende koncentreret sig om sportens fysiske aspekter. I denne sportsopfattelse synes idrætsmandens psyke nærmest at blive skrællet af kroppen, idet han/hun træder ind $\mathrm{i}$ idrætshallen. Ud fra denne ekstreme adskillelse af krop og sind leveres der så byggesten til en anden myte i den moderne borgerlige sportsopfattelse; myten om at sport og politik ikke har noget med hinanden at gøre.

Sømandspræstens udtalelse - og mange lignende citater fra sportens barndom - viser imidlertid, at sportens fædre havde en helt klar bevidsthed om, at konkurrencesporten præger - og skal præge! - psyken.

Spørgsmålet bliver da ikke om sporten kan holdes fri af politik: Politikken forstået som udviklingen af socialt ønskelige karaktertræk - er allerede på forhånd bygget ind $\mathrm{i}$ sporten. Næh spørgsmålet bliver snarere, om den „,stålsatte" karakterstruktur som konkurrencesporten fremmer stadig er socialt ønskværdig, som den øjensynlig var i kapitalismens gennembrudsfase?

Denne erkendelse af sportens indvirkning på bevidstheden medfører vigtige pointer: For det første er påpegningen af at sporten er politisk, fordi den bliver (mis)brugt som et politisk instrument alt for begrænset (boykot af OL, ,Idræt for fred“ o.s.v.). Denne form for ,,politisering“" er Dansk IdrætsForbunds topledelse jo i øvrigt også imod.

For det andet er det heller ikke nok at påpege den ,,politisering“ af sporten som foregår gennem kommercialiseringen og professionaliseringen af sporten. (F.eks. sponsorernes voksende indflydelse).

Faktisk er det en blindgyde, at indskrænke diskussionen til disse spørgsmål, fordi man herved tvinges ind i den forestilling at, hvis blot de ,,politiserende elementer" fjernedes fra sporten, ville vi igen få en ren og ubesmittet sport. Men, som jeg har vist, er dette en myte: Den ubesmittede sport findes 
ikke. Sporten påvirker menneskets karakter og er derfor helt inde i sin sjæl politisk.

\section{Køn og sport}

Spørgsmålet om sportens betydning for kønnene og deres roller er et af de mindst udforskede områder i dansk idrætshistorie. Og dette til trods for at kønsrolleaspektet er helt centralt for en forståelse af sportens væsen; hvilket jeg vil forsøge at vise i det følgende.

Hvis vi vender tilbage til sømandspræstens citat ses det, at han skifter ganske uformidlet mellem at tale om ,de Unge“ og ,han“. Dette er ikke noget tilfælde, men viser noget helt typisk ved den tidlige sport: Det var nemlig ikke kvinden, men den unge mand, som skulle stålsætte sin karakter gennem sportstræning. Eller anderledes udtrykt var det konkurrencesportens og den hårde trænings egentlige mål at smede en specifikt maskulin karakterstruktur.

Paradoksalt nok var de mandlige idrætsskribenter dog næsten ved at snuble over hinanden, når det gjaldt om at melde sig under kvindefrigørelsens banner. Gang på gang understreges det, at sporten skal medvirke til at frigøre kvinderne fra korsettet og det indelukkede og klosteragtige liv.

Men frigørelsen havde sine grænser; den egentlige konkurrencesport skulle kvinderne holde sig langt væk fra!:

„,Fremfor alt maa man ikke overanstrenge sig, thi det gælder jo ikke for Damerne at opnaa den størst mulige Hurtighed eller Kraftudvikling, men at drive Idrætten paa en let og behagelig Maade“" (Illustreret Idrætsbog s. 268, Roning).

Kvindernes plads var jo i hjemmet, og de skulle derfor ikke forsøge at nå op i samfundspyramiden. Hvorfor skulle de da dyrke „mandige Idrætter“, hvis mål var at udvikle en stålsat, opadstræbende karakter?

Hvis en kvinde alligevel skulle formaste sig til at dyrke konkurrencesport kunne man(d) fremmane skræmmebilledet af „Amazonen“, kvinden som var lige så stærk eller stærkere end en mand (gys!). Og hvis endog dette skræmmebillede ikke hjalp, ja så var der jo hensynet til kvindens skrøbelige fysik: ,En Kvinde maa paa den anden Side aldrig gøre sit Legeme til en Bunke stærkt udviklede Muskler. Hendes fysiske Betingelser er ikke skabt herfor" (Bokserbogen, Kbh. 1918, s. 20).

Kvinderne rådes derfor til at holde sig til lystsport eller til kvindegymnastikken, hvor ,Bevægelserne er blødere og smidigere, og der er en Ynde over dem, som Mændene aldrig naar. De er med eet Ord mere kvindelige" (Idrætsbogen, Gymnastik s. 40). 
Heldigvis var der enkelte (mellemlags-)kvinder som ikke bøjede sig for denne massive, maskuline ideologi. I 1890'erne brød de to kvindelige cykelryttere Johanne Jørgensen og Susanne Lindberg igennem ved at slå en lang række mandlige cykelløbsrekorder. I "Dansk Bycycle Clubs Historie“ (fra 1941, s. 102 og 106) lyder det f.eks. om Johanne Jørgensen: „Med ufattelig Energi gik hun ud efter den ene Rekord efter den anden og slog næsten alt, hvad hun kom i berøring med “ ..., ,Hun trænede energisk og satte sig som Maal at slaa de Rekorder, Mændene satte. Paa 12 Timer kørte hun $331 \frac{1}{2}$ Mil, og slog dermed Ingeman Petersens Rekord med 21/2 Mil, til trods for at hun kørte i Storm og Regn og paa opblødte Veje."

Sådanne sejre havde en utrolig vigtig symbolsk værdi $\mathrm{i}$ og med at de påviste, at kvinder kan besidde mindst lige så megen karakter, udholdenhed og kraft som mænd. Men vi mangler ikke desto mindre stadig en historieskrivning om disse kvinder, deres kampe og deres omgivelsers syn på dem.

Med denne korte diskussion af kønsaspekter ved den tidlige danske sport har jeg villet pege på flere forhold.

For det første skal kvinder og kvindekønnet ikke først optræde i sportshistorieskrivningen, idet de for alvor begyndte at dyrke konkurrencesport. Som vist er kvindekønnet allerede til stede $i$ den tidlige, maskuline sports nøglebegreb: „Den stålsatte karakter". Dette begreb bygger nemlig i sin kerne på et forsøg på at udelukke kvinderne fra konkurrencesporten. Og, i et dybdepsykologisk perspektiv, på en angst i manden for det feminine, eftergivende, svage, blide og passive element i ham selv.

For det andet mangler vi en sportens kvindehistorie, som bl.a. kan vise, hvordan kvinders karakterstruktur blev påvirket af lystsport og kvindegymnastik. Men vi mangler så sandelig også en mandehistorie. Godt nok har hele den tidlige idrætshistoriske tradition handlet om mænd, men netop ikke som køn betragtet. Derimod som repræsentanter for de bedste, hurtigste, højeste og stærkeste træk ved menneskenaturen som sådan. (I en artikel i det første nummer af Nord Nytt, 1985, vil jeg behandle sportens manderolleaspekt nærmere).

\section{Sport og klasser}

I meget af også den nyere idrætshistoriske forskning er der stærke tendenser $i$ retning af, at sporten opfattes meget entydigt, som en aktivitet, der er fælles for og dyrkes på samme måde af alle samfundsklasserne.

Nu er det ganske vist rigtigt, at sporten kan siges at blive en form for fælles sprog, der bygger bro mellem klasserne. Dette havde sportens borgerlige pionerer da også et klart blik for: 
„,Hvis Sporten tages op for Alvor af alle Klasser, vil den som i England danne et Felt, hvor alle mødes, rige og fattige, og den vil således mægtigt bidrage til at udfylde Kløften mellem de forskjellige Samfundslag" (W. Hovgaard, Sport 1888 s. 6).

Lidt firkantet kan man i dette lys forstå sporten som en borgerlig ,,strategi“ til passivisering af den før århundredeskiftet socialt urolige og truende arbejderklasse.

Men samtidig var begrundelsen for arbejdernes deltagelse i sporten i den borgerlige idrætslitteratur aldrig karakterudvikling og drømmen om den sociale opstigning. Begrundelsen var derimod, at arbejderne havde behov for organiseret fysisk udfoldelse som en modvægt til det hårde, ensidige og nedslidende arbejde. Altså gendannelse af arbejdsevnen fremfor karriere. Men forskellen mellem arbejdernes og borgernes sport stak endnu dybere: I et citat fra den borgerlige sports flagskib, tidsskriftet „Idræt“, hvori der bejles til Arbejdernes Bicycle Club om at abonnere på bladet, ses det at sociale forskelle inden for sporten var alment kendt:

„At Cykling er den folkekæreste Sport er let forstaaeligt. Rigmanden som dyrker Sport, som har Baad i Vand og Cycle paa Land og Tennis - plads og Fægtesal, han ferierer flere Gange om Aaret borte fra daglige Omgivelser. Arbejderen, Smaaborgeren har ikke Raad til alle disse Herligheder, og hverken Raad eller Tid til at ligge paa Landet. For ham er Cyklen alt, Befordringsmiddel, Sportsredskab ... Cyclen er med andre Ord hans Landssted, hans Villa.“ (Idræt 1901 s. 10).

Men - hvad der er endnu vigtigere - de første arbejdersportsfolk overtog ikke blot sporten som et færdigt produkt, men formede den i vid udstrækning efter deres egne normer, og brugte den til deres egne formål. Og dette foregik på i hvert fald to forskellige måder:

For det første dannede arbejderne klubber inden for sportsgrene, hvor deres særlige klassemæssige værdier var i højsædet. I fodboldspillet kunne arbejderne f.eks. dyrke sammenholdet, som jo var blevet en helt fundamental forudsætning for især den faglærte arbejderklasses sociale og politiske frigørelseskamp. Og i kamp- og styrkesport som f.eks. vægtløftning, brydning og boksning, kunne de dyrke det maskuline styrke- og muskelideal, som i høj grad trivedes blandt kroppens arbejdere.

For det andet medførte arbejdernes indtog $\mathrm{i}$ fodboldspillet en forandring af dette spil. De tidlige borgerlige fodboldklubber var stærkt præget af en individuel spillestil. Efter 7 års erfaring med fodbold siges det f.eks. om den største borgerlige boldklub KB: „Aflevere til hinanden kendtes ikke, alle spillere styrtede blot i Flok efter Bolden“ (KB gennem 75 Aar, 1951).

Men med de første arbejderklubbers opståen skete der en forandring af fodboldspillet i retning af en kollektivistisk, men også mere rå, spillestil. Og 
efterhånden blev denne nye spillestil også overtaget af de borgerlige klubber. (Anders Berthelsen, Frispark, 1983).

Alt for ofte beskrives arbejderkulturen som en efterligning af, og en efternøler i forhold til borgerskabets kultur. Men dette er en forsimpling, hvilket bl.a. eksemplet med kollektivisme- og styrkeidealet kan vise. Det kan altså tværtimod hævdes, at arbejdernes sportsdyrkelse netop betød, at deres egne klassemæssige værdier kom til ære og værdighed. Og at den også havde en afsmittende effekt på andre klassers kropskultur.

Dette samspil mellem forskellige klassers kropskultur peger i øvrigt også på, at en klasses historie ikke på nogen meningsfuld måde kan beskrives isoleret. Klassekulturerne udvikler sig altid i et samspils- og modsætningsforhold til hinanden, og de skal derfor analyseres inden for dette spændingsfelt.

Dette gælder selvfølgelig også borgerskabets kropskultur: Med arbejdstidens nedsættelse og reallønnens stigning fik især de mandlige, faglærte arbejdere omkring århundredeskiftet efterhånden mulighed for at dyrke sport. Dette medførte interessant nok også ændringer i overklassens sportsdyrkelse. Nu var det ikke længere fint at dyrke fodbold eller cykling, det kunne enhver jo gøre. Nej, der måtte nu helt anderledes dyre sportsgrene til for at understrege den sociale førerposition.

F.eks. vandt tennis kraftigt frem i KB allerede før århundredeskiftet, og udkonkurrerede derved fodboldspillet som vigtigste boldspil. Sejlads og ridning beholdt deres præg af overklassefornøjelse, og efterhånden kom helt nye sportsgrene til som forenede den nye tids fascination af fart og teknik med sportslig konkurrence først og fremmest Automobilsporten. Når man drønede ud ad landevejen i sin nyerhvervede bil kunne man i det mindste være sikker på ikke at blive forstyrret af de lavere lags fodsved og trampen $i$ pedalerne.

Det foregående har i stor udstrækning været baseret på ,ideologisk kildemateriale", altså spørgsmålet om hvordan klasserne opfattede deres egen og hinandens deltagelse i sport. Men vi mangler i lige så høj grad egentlige historisk-sociologiske undersøgelser af klassernes deltagelse i de forskellige sportsgrene. Og ikke mindst udgør spørgsmålet om den skarpe klassemæssige opdeling, som tilsyneladende fandtes i den tidlige sport, også eksisterer i dag, et helt centralt forskningsfelt.

Som en opsummering på de fire forgående afsnit vil jeg sige, at når Ove Korsgaard i sit idrætshistoriske værk „Kampen om kroppen“ fra 1982 slår fast, at sportens mål var ,,karakteropdragelse“, så kan det præciseres at:

1) Målet var at udvikle ,,en stålsat karakter" med centrum i selvbeherskelsen og kontrollen over kropslige impulser; og denne selvbeherskelses mål var at komme til tops i samfundet. 
2) Eftersom kvinderne, ifølge den tidlige idrætslitteratur, ikke skulle opad i samfundspyramiden var det også ganske logisk, at ,,den stålsatte karakter" udelukkende var et ideal for mandepsyken: Konkurrencesportens mål var altså at udvikle en specifikt maskulin karakter.

3) De mandlige arbejdere måtte, ifølge idrætslitteraturen, gerne dyrke konkurrencesport, hvis de da havde tid og råd. Men den egentlige grund til arbejderes sportsdyrkelse var angiveligt, at dette kunne skabe en modvægt til det nedslidende kropsarbejde, altså en rent fysisk argumentation.

\section{Sportsbistand}

Et af de efter min mening væsentligste forskningsfelter er studiet af sportens' møde med fremmede kropskulturer. Sådanne møder fortæller os ikke alene noget om de fremmede kropskulturer, men i høj grad også om sporten.

Ved mødet med det fremmede bliver det lige pludselig klart at der i mennesket findes mange - ja ubegrænsede - muligheder for at bevæge sig på forskellige måder. Og dermed åbnes der også for at forstå at den vestlige konkurrencesport kun er én form for kropslig udfoldelse blandt mange tusinde andre. Derfor bliver det også i sidste ende et valg om vi vil følge konkurrencesportens idealer, eller om vi vil dyrke noget helt andet, eller tredje, eller...

Det uhyggelige er bare, at der tilsyneladende mange steder i verden i dag gøres helt bevidste forsøg på at udbrede sporten på bekostning af ofte ældgamle, traditionelle kropskulturer.

For at belyse denne proces vil jeg starte dér, hvor det hele begyndte; i det nittende århundredes England. Jeg vil dog understrege, at min viden om sportens internationale fremmarch er meget begrænset - delvis fordi der på dansk grund endnu er tale om en relativ spinkel forskningstradition. Men dette er kun endnu en god grund til at fremhæve dette forskningsfelts betydning.

Storbritanniens placering som det 19'ende århundredes førende kapitalistiske samfund udtrykte sig ikke blot i en forrygende vare- og kapitaleksport og opbygningen af det 19'ende århundredes største kolonirige. Også på kropskulturens område blev Storbritannien efterhånden den dominerende nation. Sportsbevægelsen startede her, men bredte sig snart til andre kapitalistiske lande $\mathrm{i}$ takt med deres integration i det kapitalistiske verdensmarked.

Overalt måtte de gamle ,umoderne“ kropskulturer vige pladsen for den nye tids bevægelser. Dette skete dog ikke altid lige gnidningsfrit: I Danmark f.eks. var den dominerende form for kropskultur i slutningen af det 19'ende 
århundrede gymnastikken. Og for gymnasterne var det tilsyneladende ikke særligt indlysende, at man nu udelukkende skulle springe højdespring for at komme så højt op som muligt. De mente tværtimod at det vigtigste måtte være hvor smukt springet så ud. (K. A. Knudsen, Om sport, 1895).

Britiske handelsfolk, opdagelsesrejsende og missionærer bragte også sporten med ud til kolonierne i den 3. verden, men i dag optræder denne sportseksport i en moderne variant: Den har nu form af en gave fra vores rige „overflodssamfund“ i vest til de fattige ,underudviklede“ befolkninger i syd.

For eksempel tog den internationale olympiske komite i 1969 initiativ til dannelsen af en olympisk solidaritetsfond. Denne fonds formål var at støtte udbredelsen af de olympiske sportsgrene over hele jordkloden og ikke mindst $\mathrm{i}$ den tredje verden. Denne proces deltager også mange af de internationale specialforbund i (Jvf. Lisbeth Gormsen, Sportsudvikling i Tanzania, Centring 1983/2 s. 77).

Men ikke nok med det; sporten får også en stadig større rolle i u-landsbistanden. Som et helt aktuelt eksempel kan nævnes, at det svenske idrætsforbund i samarbejde med bistandsorganet SIDA for få år siden startede et såkaldt „Sport for alle“ projekt i Tanzania (Jvf. Niels Larsens artikel i Information 22/6 1984). Målsætningen synes at være, at de stakkels, underudviklede tanzanianske stammefolk ikke længere blot skal hjælpes med deres mistrøstige økonomiske problemer. Næh, nu skal de sandelig også have del i vores overlegne kropskultur. Og dette til trods for at f.eks. både sukumaernes og masaiernes kropskultur indeholder en skønhed, som man skal være sportsidiot for ikke at kunne se.

„Længdespring foregår ved, at masaierne springer over to streger tegnet $i$ sandet eller over to kæppe. Afstanden øges ved, at mellemrummet mellem stregerne eller kæppene gøres større. Alle kan imidlertid springe med så længe de har lyst; det sker ikke at personer bliver udelukket fra at springe fordi de lander i mellemrummet. Ingen taler om præstation eller tænker over hvem der er bedst: Alle forsøger at gøre deres bedste og nyder selve aktiviteten." (Lisbet Gormsen, ibid. s. 81).

Konkret foregår sådanne bistandsprojekter $i$ et samarbejde med de lokale magteliter i den tredje verden, som dels ønsker at sporten skal gavne landets prestige udadtil f.eks. i form af medaljer ved OL. Dels er der sandsynligvis også tale om et mere eller mindre bevidst ønske om at skabe mere „tidssvarende " og præstationsbevidste holdninger i befolkningen.

Det mest absurde ved hele denne sportsbistandsidé, er imidlertid, at den foregår på et tidspunkt, hvor flere og flere mennesker i den vestlige verden er begyndt at opfatte sporten som en spændetrøje. Og hvor disse mennesker har fået øjnene op for den rigdom i kropslige udtryksformer, som findes over alt på jordkloden: 
Der har således i Danmark aldrig før været dyrket så megen ikke-europæisk kropskultur som i dag: som eksempler kan nævnes tai chi, aikido, judo, karate, yoga, meditation, samba, capoeira o.s.v.

$\mathrm{Nu}$ er ,ikke-europæisk kropskultur“" jo ikke automatisk det samme som ,,ikke-sport“. Og dette skyldes, at sporten ikke blot fortrænger andre kropskulturer, men også forandrer dem i sit billede, altså gør dem til moderne konkurrencesportsdiscipliner. Som et eksempel på dette vil jeg nu diskutere den japanske kampkunst judo. Dels fordi det er den form for kropskultur jeg kender bedst, men også fordi den er et godt eksempel på en traditionel kropskultur, som omformes til en moderne konkurrencesport.

\section{Judoens forvandling til moderne konkurrencesport}

De moderne olympiske lege kan groft sagt beskrives som den vestlige sports udstillingsvindue.

Skønt alverdens nationer tilsyneladende higer efter at deltage og først og fremmest vinde i legene, findes der kun ganske få eksempler på ikke-vestlig kropskultur på det olympiske program.

Det eneste eksempel jeg kender er judo. At judo kom på det olympiske program i 1964 må imidlertid ses i forbindelse med flere forhold. For det første var det et udtryk for, at Japan nu - både hvad angår bruttonationalprodukt og forventet medaljehøst ved OL - var rykket op i nationernes førstedivision. Det var derfor heller ikke noget tilfælde at OL i 1964 blev afholdt i Japan.

For det andet, og vigtigere, var den judo som her blev præsenteret en totalt sportsliggjort form for judo med regler, dommere, pointsystemer og konkurrence som de centrale elementer.

Oprindeligt var konkurrenceelementet imidlertid af helt underordnet betydning inden for judoen, som nærmest kan beskrives som en form for meditation i bevægelse.

Selve ordene ju do betyder faktisk ,den milde vej“ ", og grundideen i judo som selvforsvar er, at en fysisk overlegen voldsmands angreb skal ledes ind $i$ en cirkulær kastebevægelse, der anvender hans egen kraft mod ham selv. Med den legendariske judomester Kyuzu Mifunes ord: „Mildhed overvinder stivhed" (Fra Mifunes bog: Judo kaikoroku, 1956, Tokyo).

Men i og med at judoen omformes til konkurrencesport, sker der ofte en omvending af dette princip til ,stivhed overvinder mildhed".

Angsten for at tabe bliver den dominerende driftkraft. Og konkurrencereglerne favoriserer i mange situationer en form for muskeljudo, som gennem råstyrke, stive arme og bøjede rygge desperat søger at undgå det forsmædelige nederlag. 
Denne form for koncentration om ens eget ego i kamp mod en fjende var netop det, som skulle undgås i den oprindelige judo. Igen med Mifunes ord: ,Når man kæmper mod en stærk modstander findes der egentlig ingen modstander: Essentielt skal man overgå jeg'et". Man skulle altså leve sig så stærkt ind i judo'en, at man glemte både sig selv og modstanderen.

Det vigtigste i den traditionelle judos idé, var altså ikke at tyre modstanderen, men at indgå $i$ et så tæt samspil med ham, at bevægelserne gik ud $i$ et. Begge parter skulle bruge hinanden som slibestene, for at udvikle sig.

Dette viser sig også sproghistorisk, idet betegnelsen for den som kaster og den som bliver kastet er henh. tori og uke. Tori betyder den som tager, mens uke betyder den som modtager. Begge får altså noget. Der er ingen vinder. Ingen taber. (Tak til Eiki Ishizaki fra Kata/star judoklub for de japanske oversættelser).

Der findes dog stadig japanske kampkunster, som stort set er uberørt af sportslige ideer og dyrkes traditionelt i Vesten. Et eks. på dette er aikido, som bygger på noget så usportsligt som den frie cirkulation af ,,livsenergi“" gennem meditative bevægelser, og hvor enhver form for råstyrke og konkurrence er bandlyst.

Men selv inden for aikidoen findes der tendenser til at udbrydergrupper skaber en ny form for konkurrenceaikido, ikke kun i vestlige lande, men også i Japan selv.

Men igen har vi den paradoksale situation, at samtidig med sportsliggørelsen af de japanske zenbuddhistiske kampkunster, er enkelte vestlige sportsfolk begyndt at dyrke moderne konkurrencesportsdiscipliner som tennis, golf og løb ud fra den traditionelle japanske kampkunsts principper. Nu er det ikke længere resultatet (sejren, medaljen, rekorden), der betones, men der tales om ,,dybtgående grænsesprængende oplevelser" og en følelse af enhed mellem udøveren og hans redskab. (G. Leonard, The Ultimate Athlete, New York, 1975, Michael Murphy and Rhea A. White, The Psychic Side of Sports, Massachusetts, 1978. Michael Murphy, Sport som yoga, Centring 1982/3-4 s. 172ff).

Heldigvis findes der også eksempler på, at det ikke altid er den vestlige sport, der går sejrrigt ud af sammenstødet med fremmede kropskulturer, selv om det ikke ligefrem er sådanne eksempler, som dominerer forskningen eller avisoverskrifterne i den vestlige verden. Som et eksempel kan nævnes, at det engelske cricketspil blev indført på Trobriandøerne ved dette århundredes begyndelse. Det spilles stadig, men nok ikke helt med den oprindelige engelske sportsånd:

„,Alle der er samlet for at spille kan være med. Hver kamp begynder med en styrkedemonstration for de deltagende hold. I formationer der minder om engelske soldaters militære eksercits indtager holdene spillepladsen. Nye 
viser er digtet som forherliger holdets spillestyrke. Det drejer sig ikke om at vinde - alle spil er uafgjorte - men om at vise at man på hver sin måde er en god spiller. Spillet er underkastet magiske kræfter. Dommeren, som selvfølgelig selv kan deltage, har ret til under spillets gang at anvende magi for eller imod de deltagende hold" (Fra kataloget over de film, nordisk antropologisk filmklub råder over, sommeren 84).

Som en opsummering af de to sidste afsnit vil jeg sige, at den dominerende tendens i dag synes at være at sporten bruser frem over hele jordkloden og fortrænger eller forandrer andre kropskulturer i sit eget billede. Men samtidig er der også tale om (meget forskelligartede) modgående bevægelser: Stadig flere mennesker i den vestlige verden dyrker i dag forskellige former for alternativ kropskultur eller forsøger at dyrke sport på en så alternativ måde at man næppe længere kan tale om egentlige sportsaktiviteter. Og eksemplet med ,,det magiske cricketspil“ viser, at fremmede kulturer kan besidde en kulturel modstandskraft, som endog formår at omforme konkurrencesporten i deres eget magisk-religiøse virkelighedsbillede.

Inden for alle disse felter ligger der helt oplagte forskningsmuligheder. 